\title{
PNG's Year of the Gun
}

All of us who practise journalism in PNG need to be ready for challenging times ahead. It is up to Government to properly explain its policies, and that's something the current PNG Government has not done well of late. And it is up to the media to take a lead role in informing, rather than inciting, public debate.

\section{By RICHARD DINNEN}

"I THINK the situation is under control," said Colonel David Takendu as he stood before the Port Moresby media assembled at Murray Barracks, the Papua New Guinea Defence Force headquarters. And in a very Melanesian way, he was right, even though the situation that developed at Murray Barracks in March this year was a major crisis, the first of two in Papua New Guinea this year. PNGDF soldiers had taken weapons from the Murray Barracks armoury, with the apparent consent or assistance of their superiors, and had begun an armed protest in the residential section of the Barracks, demanding a meeting with Prime Minister Sir Mekere Morauta.

If and when the Prime Minister agreed to meet the soldiers, they would demand that the Government abandon its planned Defence Force reforms, the most controversial of which was a troop cut of about 50 percent. The reforms had been recommended by a group of foreign experts commissioned by the PNG Government, after PNG soldiers burned down a barracks in Wewak during celebrations of PNG's Independence Silver Jubilee and the now infamous gun battle between soldiers and PNG police in the streets of a Port Moresby shopping district.

Colonel Takendu's assurance that the situation was under control on that hot March afternoon was one of the most telling statements made during the military crisis. Soldiers had taken up arms with the intention of forcing their Government to abandon a policy that Government considered crucial to the country's future. 


\section{RICHARD DINNEN}

Reporters struggled with dictionary and thesaurus to find the right word, uprising, insurrection, mutiny and rebellion all fell short of the mark. I stuck with armed protest, and clearly the PNG Government operated for several days with a gun at its collective head.

So how could Colonel Takendu say the situation was under control? To reporters who haunted the Murray Barracks area during those tense days, it seemed clear that it WAS under control in that it was all going exactly to plan, and that the rebellious soldiers had the tacit support, if not the outright endorsement of very senior PNGDF officers. Certainly very little was done by the military to end the armed protest or to curtail the movements of the protesting soldiers, who were able to move weapons and ammunition around with apparent ease.

\section{The Murray Barracks armed protest}

As the days went by and journalists worked around the clock to cover the story and filter the facts from the rumours, the Prime Minister continued to refuse a face-to-face public meeting with the soldiers, preferring to send his Defence Minister Kilroy Genia to deal with them. Several days in to the crisis, NBCRadio News ran an item suggesting the Prime Minister would attend a meeting with soldiers on the football field at Murray Barracks that afternoon. Much argument has raged since then about whether or not the item was correct, but it certainly created the impression that Prime Minister Morauta would attend.

The Defence Force brass invited the media to the meeting, and we attended in large numbers, with the proceedings to be broadcast live on local radio. A large crowd sat in the shade around the football field, while senior officers stood on a small dais in the centre of the ground. The mood was light, jokes were being called out and for the first time in many days we felt a solution might be at hand.

Defence Minister Genia and his party made their way to the dais, and a delegation of soldiers came forward to present a petition of demands and grievances. In the crowd, shouts began to be heard. "Praim Minista I stap we?" Where is the Prime Minister? The chorus grew louder, more threatening, and people began to rise and move slowly, at first, towards the dais, picking up speed as they went. The first wave reached the dais, smashed a public address system, tore down the roofing of the dais, as hundreds more charged towards the media. They carried pieces of wood, lengths of metal pipe, and they raced towards us, shouting and swearing.

Australian Associated Press journalist Kevin Ricketts was punched, my cameraman Peter Dip was struck in the head and forced to surrender his camera 74 PACIFIC JOURNALISM REVIEW 7:1 2001 


\section{I was in shock, get- ting through my} work on adrenalin discipline that find in times of crisis

a curious mix of bloody-minded determination to tell the story and a view that the show must go on. and the strange broadcast journalists

tape. I was struck with a length of pipe, and threatened by a man I recognised as a soldier, who told me he knew where I lived and that he would deal with "you ******* Australians" in a most violent manner.

The media was chased away, with military police escorting us, but it's still not clear to me whether they were protecting us or helping the mob. From a distance, I watched the angry mob surround the dais, on which senior officers and Defence Minister Genia still stood, and it seemed to me that they somehow knew that they would not be attacked. Just as quickly as the trouble began, it ended, with Genia walking past a few minutes later making the dubious observation that the media should not sensationalise what had just happened. His Defence Force was holding his Government hostage, his soldiers had just attacked journalists, yet Genia somehow felt this was not an outrage.

In the ensuing chaos, soldiers stole $A B C$ equipment, including a two-way radio I was using to attempt to locate my colleague, Dulciana Somare. She had joined the $A B C$ just a few days before this incident, and this was one of the first occasions we had taken her out on the road as a reporter. I feared for her safety, but she had spotted the trouble brewing, kept her head and managed to make her way back to the $\mathrm{ABC}$ office, where we sat, my. hands trembling as I drank tea and began the long slog of turning what had just happened into TV and radio reports.

I was, I think, for much of that afternoon and night, in a state of shock, getting through my work on adrenalin and the strange discipline that broadcast journalists find in times of crisis, a curious mix of bloody-minded determination 10 tell the story and something from the tradition of the theatre, that the show must go on. It did. The ABC and the other media there that day lived to tell the story, and see the crisis through to its end. The Prime Minister agreed to meet a delegation of the soldiers, who presented their demands to him at his official residence near Parliament House. The reforms were abandoned, and the PACIFIC JOURNALISM REVIEW 7:1 200175 


\section{RICHARD DINNEN}

Government said it would begin again the process of determining how the PNG Defence Force could be made to work affordably. The soldiers told their Prime Minister that they had given him a clear message, that they would rise up against anything they felt was not in the best interests of the people, the country, or themselves. And Prime Minister Morauta told us that on that day, it had been proved that democracy was alive and well in Papua New Guinea.

In the sense that the Government had acted on the expressed will of some of its citizens, he was right. But was it the will of a majority of PNG citizens, and what precedent had been set by giving in to people who had used weapons to achieve their aims, who had broken the laws of the land despite being members of a supposedly disciplined force, who had committed theft and assault, and who were granted an amnesty for their actions even before they had surrendered the weapons?

And the potential for more trouble in the PNGDF ranks remains. The issues that led to the crisis, the years of neglect by successive PNG governments, the chronic lack of resources, the inattention to discipline, they all remain. The Government says it intends to find other ways to reform the PNGDF, but at time of writing, has not communicated its intentions publicly. Future attempts at reform could well meet the same fate.

\section{The privatisation protests}

Guns were also an eventual feature of Papua New Guirea's second crisis of 2001 , the protests against the Government's privatisation programme, that ended in violent confrontation and the death of four young men. The Government has long been of the view that the only hope for saving the PNG economy is to sell off state-owned assets such as Telikom, the technically insolvent Post PNG, Air Niugini, Elcom and the like. These outfits have provided poor services and have been an enormous drain on Government revenue for many years. The Government believes that it can barely afford to private core services, so it should not be running a phone company or an airline, and in that, they're probably right. But the arguments for and against privatisation continue to rage in many nations, and whether or not it's an appropriate solution for PNG is not for the media to decide.

But in PNG, the privatisation concept is seen by many as the work of foreigners. It is being actively promoted by PNG's foreign supporters, such as Australia, the International Monetary Fund and the World Bank. In fact, some foreign financial assistance is conditional on PNG promptly moving towards 76 PACIFIC JOURNALISM REVIEW 7:1 2001 


\section{Politicians have}

\section{seized on the issue}

as what they think

will be an effective

weapon against the

Sir Mekere Morauta

Government for next

hoping to use

privatisation to

portray it as doing

the biding of

foreigners. year's election

privatisation. As with the Defence reforms that sparked the military crisis in March, privatisation is being portrayed as a foreign solution being forced on PNG in return for aid. Some resent the strings apparently attached to foreign aid, others hold fears for the quality of service they might get from privatised banks and utilities.

And politicians have seized on the issue as what they think will be an effective weapon against the Government in the lead-up to next year's election - hoping to use privatisation to portray the Morauta Government as doing the bidding of foreigners who have a sinister agenda.

Students at the University of Papua New Guinea took it upon themselves to begin a campaign of public awareness on privatisation during June 2001, when they believed the Papua New Guinea Banking Corporation would be sold off. They took to the streets and settlements of Port Moresby, delivering a message that seemed to quickly take hold with

citizens - that privatisation is evil and should be opposed.

Within days, a large scale public protest began, with demonstrations at the Government buildings in Waigani and at several other locations. The main focus was at the office building housing the Prime Ministers Department, where a sitin continued for several days. The students, and their thousands of supporters demanded a face-to-face public meeting with Prime Minister Morauta, as the soldiers had done in March. Sir Mekere refused, saying his office was not something that could be dragged through the streets, and he sent a delegation of Cabinet Ministers in his place. The protesters booed them off and sent them away, refusing to hand over a petition of demands. Eventually, the Prime Minister relented, and led his Cabinet ministers down to the street for what was a sometimes tense meeting with the crowd. Sir Mekere does not seem comfortable or fluent in Tok Pisin, and his speech to the protesters fell short of what they wanted to hear, both in content and delivery. He reaffirmed his Government's 


\section{RICHARD DINNEN}

intentions to do its best in difficult economic circumstances, but he was not well received. He accepted the list of demands, promising at least a partial response within 24 hours.

Until that point, the protests had been peaceful, if disruptive, and while they had featured prominently in news coverage, they did not attract the degree of attention or scrutiny that they now seemed to deserve. It was probably the most organised, best-controlled public protest I have seen in many years of reporting, and by PNG standards, it was impeccably conducted. There were opportunists and criminals working around the edges, and some violence and vandalism had been reported elsewhere in town, but it was still possible to believe that the core group of protesters were not responsible for those acts.

But just a few hours after the meeting with the Prime Minister, when many of us believed the protest would end next day, the PNG police upped the stakes. Perhaps a change of commander in the preceding days had been a factor, but police were now preparing to take a tough line. Protesters were saying at that point that they would abandon their sit-in the next day, after receiving the Prime Minister's response. But police were no longer in the mood to wait. They moved into the small crowd remaining on the street outside the Prime Minister's office, issued orders to disperse, and then fired warning shots in the air. They then moved in and forcibly broke up the protest, using tear gas to disperse the crowd.

What happened next remains the subject of intense debate, and a Commission of Inquiry has heard conflicting evidence relating to subsequent events. Students appear to have fled the scene of the protest, returning to the UPNC campus not far away. Acts of vandalism were committed in the area, but the evidence is sketchy as to who did it. Some time later, the UPNG students claim they were inside the campus when a PNG Police Mobile Squad flown in from Mount Hagen a few days earlier arrived, and proceeded to storm the campus, firing high-powered weapons. Four men, three of them students, were shot dead, many others were injured, in a battle that raged all night and into the following morning.

In the days that followed, an angry and volatile atmosphere prevailed in Port Moresby. Once again, one of the country's so-called disciplined forces had acted in a way that seemed to have gone well beyond what was called for. Never before had the disciplined forces attacked their own civilians in such a way, and the outrage was everywhere. It was not safe for journalists to go to the campus or to other places where people were gathering to vent their anger, exercise their curiosity or take advantage of the instability. Drivers were being attacked in 78 PACIFIC JOURNALISM REVIEW 7:1 2001 
The campus was a

chilling sight. A

place of learning

littered with spent

bullets, fences

knocked down,

lights deliberately

shot out, bullet

holes in the walls

and windows.

Whoever had fired

the shots certainly

intended to harm. their cars, stores had been looted or burnt down, businesses shut their dools and public transport ceased to exist. The $\mathrm{ABC}$ shared the cost of hiring a helicopter with local media, to get above the dangers and have a look at the results. Port Moresby is not my home town, and I have to confess that it is a town that I don't particularly like. But I have lived here for almost three years, and it was indeed sad to see sections of it smouldering, demolished, and under mob rule.

As with the military crisis, rumours and wild gossip began to circulate, and filtering fact from fantasy became an almost impossible task. And once again, the events were almost inexplicable. After two tense days of negotiation, the students invited me on to the university campus to inspect the scene, and it was a chilling sight. A place of learning littered with spent bullets, fences knocked down, lights deliberately shot out, bullet holes in walls and windows. Whoever had fired the shots certainly intended to harm.

But there was also the burnt out remains of a car belonging to a local TV crew, who had been attacked, apparently by students, the day before. The students had repeatedly criticised the local media coverage of the protests and the subsequent violence, claiming it was biased against them. They were not backward in making their feelings known on this score, and some went further than they should in making their point. They did not go as far as the soldiers at Murray Barracks had done in March, but clearly, journalists working in PNG can expect retaliation or retribution it people disagree with their reporting of events.

The students claimed to have photos and videotapes of the protests and the subsequent violence, which I offered to broadcast. But despite repeated attempts to secure this evidence and publish it, the students never delivered. Instead, they made lengthy statements in front of the $A B C$ camera, claiming that they had exercised their democratic right to stage a peaceful protest, and that police had responded with unprovoked violence. The police were keeping silent, but were 


\section{RICHARD DINNEN}

clearly angered by the $\mathrm{ABC}$ coverage as the days went by. The PNG Police Force does have a media relations office, but in my nearly three years here, I have only ever received one unsolicited communication from that office. During this crisis, the police did nothing to put their version of events to the ABC.

Journalists are supposed to be impartial, and the good ones go to great lengths to balance their stories and remain neutral. This story tested my resolve, because on the face of it, with the information available, the only conclusion was that the police had in fact launched an unprovoked attack on a place of learning long after what they called an "illegal" demonstration had been broken up. Emotions were running high, and the demands for compensation for the dead began to be heard. Attempts were planned to seize their bodies and carry them to Parliament for another protest, but these did not succeed. The hospital morgue where the bodies lay became another flash-point, and the funeral service eventually held at the university campus for three of the dead was a tense occasion. Sections of the crowd became angry during a fiery speech by the Speaker of Parliament, Bernard Narakobi, and for a moment, I feared I and my $A B C$ crew were about to be in the middle of another episode like the riot at Murray Barracks during the military crisis. But thankfully the moment passed, the event continued with dignity, and the media were allowed to do their job.

The Prime Minister promised a Commission of Inquiry into the violence, the protests, and into allegations that some of it had been fomented by "certain politicians". As in the military crisis, the Government suggested its opponents were behind the troubles, stirring things up or actively supporting events. But when challenged to name names, the Government fell silent. The establishment of the Commission of Inquiry and the appointment of a Commissioner took much longer than the Prime Minister had said it would, and the delay of several weeks went unexplained. Eventually, former judge Sir Robert Woods was appointed, and given broad terms of reference. At time of writing, he has been hearing lengthy and often conflicting evidence, with students claiming they were the victims of an unprovoked attack, while police and others say the students threw Molotov cocktails and may have used other weapons against the police. It took many weeks, and skilful leadership, to get the UPNG campus back to normal, but even now, the scars left by these events are visible.

\section{Challenges for the media}

The military crisis in March was a curious one, in that while it drew attention world-wide and paralysed Port Moresby for almost two weeks, it would have 80 PACIFIC JOURNALISM REVIEW 7:1 2001 
been possible for a naïve visitor to step off an international flight, drive into Port Moresby and not be aware anything unusual was going on. Apart from a flurry of activity around Murray Barracks, life seemed normal for those not directly involved. It was strange for me to spend two weeks of my life working around the clock, intensely following every development, but in the few spare moments I had to step out of the office, the town seemed normal in every respect. That was not the case in June, following the protests, when Port Moresby was a very unpleasant place to be. The disruption was total for many days, and an overnight curfew imposed during the crisis remained in force for two months. It was August before we felt life had returned to anything like normal.

In any time of crisis, effective communication is critical. The PNG Government was quick to condemn media reporting during the military crisis, yet its own performance in communicating with the media was less than effective. While Defence Minister Kilroy Genia did make himself available to brief the media, the Prime Minister did not, citing security concerns. When the Government announced that it would abandon the Defence reforms, it did so by way of a brief faxed statement. The Prime Minister's Media Unit then said there would be no media conference, but local television station EM-TV would be allowed to record an interview with him that would be distributed to other media. When my copy of the tape arrived, I put it into my player and saw pictures of US televangelist Benny Hinn. After spooling the tape, I found the piece with the Prime Minister, but the sound was almost inaudible. The recording had been largely drowned out by the sound of an electronic swimming pool filter, which is a regular problem when recording the Prime Minister at his residence. Most of us struggled to hear what he had to say, and it should be no surprise if the message was subsequently scrambled by some.

The two crises endured by the people of Port Moresby this year posed many challenges for the media. They were times of extra pressure on journalists and their media organisations, in a place where even a quiet news day can be a major challenge. Reporters faced danger, threats, intimidation, and were required to report on events in which the behaviour of two of their nation's disciplined forces were called into serious question. By and large, the crises were covered accurately and fairly, despite considerable obstacles. But many unanswered questions remain, from both events. The issues that gave rise to them remain unresolved in the minds of many people, and the PNG media is canvassing the issues. With an election due next July, these and other iss!ıes will remain in the public eye. 


\section{RICHARD DINNEN}

All of us who practise journalism in PNG need to be ready for challenging times ahead, and we should all look for ways to shift the focus of our work from the hour by hour reporting, to more considered analytical and investigative material. In both crises this year, there were those who claimed, with some justification at times, that the public thinking and sentiment that drove the crisis was ill-informed, and that the issues, especially privatisation, were not well understood. It is up to Government to properly explain its policies, and that's something the current PNG Government has not done well of late. And it is up to the media to take a lead role in informing, rather than inciting, public debate.

$\square$ Richard Dinnen is the Australian Broadcasting Corporation correspondent in Papua New Guinea. abcpng@ daltron.com.pg

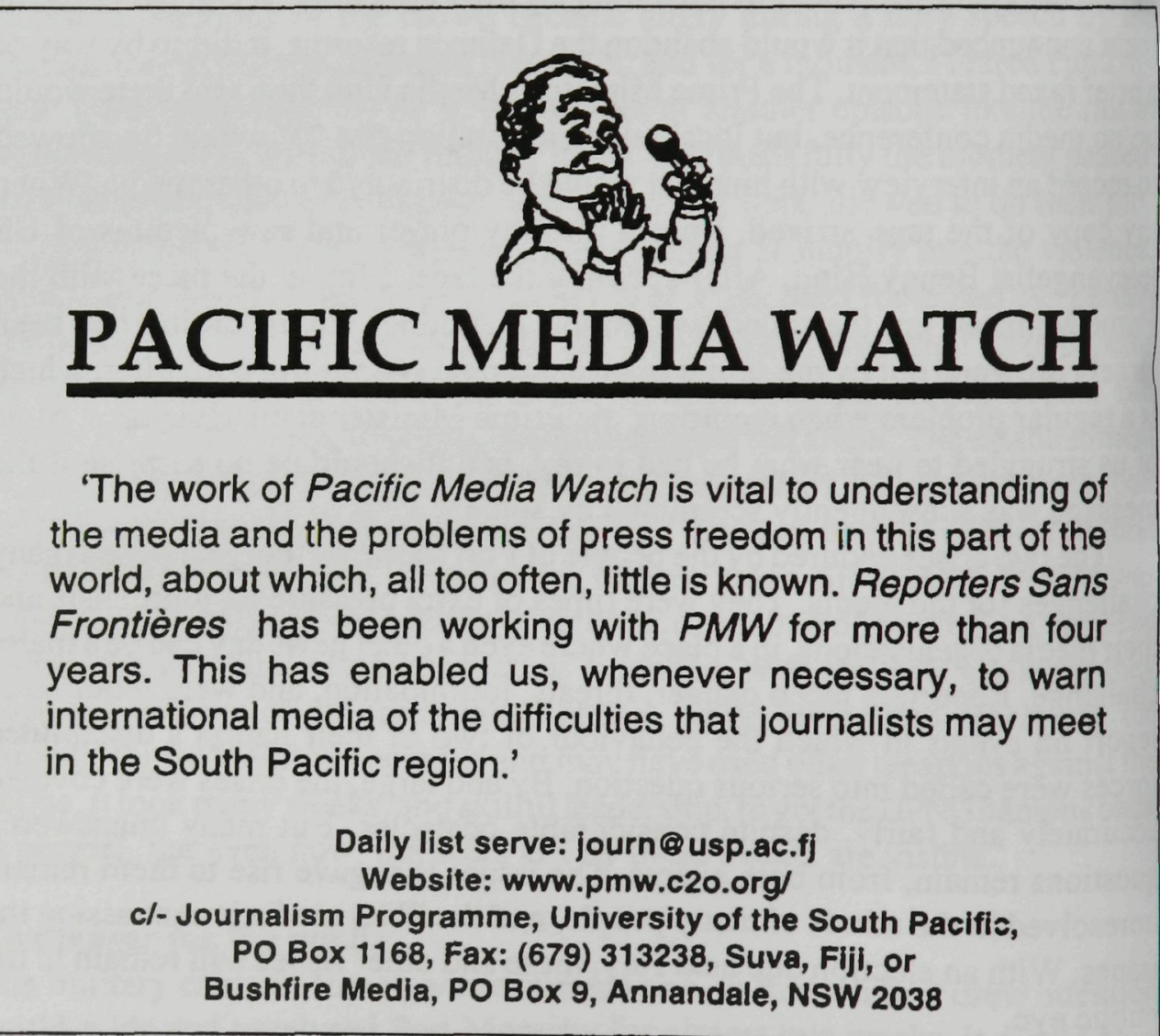

82 PACIFIC JOURNALISM REVIEW 7:1 2001 